\title{
Micronutrient requirements and effects on cellular growth of acetic acid bacteria involved in vinegar production
}

\author{
Vitório dos SANTOS JÚNIOR ${ }^{1}$, Érico NIZOLI ${ }^{1}$, Diego GALVAN ${ }^{2}$ (D), Rodrigo José GOMES², Guilherme BIZ³, \\ Jéssica Barrionuevo RESSUTTE², Thais de Souza ROCHA², Wilma Aparecida SPINOSA ${ }^{2 *}$ (D)
}

\begin{abstract}
This study aimed to verify the need for minerals and vitamins to increase the production of cell mass by acetic acid bacteria (AAB) isolated from the vinegar industry (086/06) and standard strain (Acetobacter aceti CCT 2565). Five minerals (Mo, B, Zn, $\mathrm{Fe}$, and $\mathrm{Mn}$ ) and eight vitamins ( $p$-aminobenzoic acid, thiamine, niacin, pantothenic acid, pyridoxine, biotin, cyanocobalamin, and inositol) were tested in a fractional factorial design. To prepare the inoculum, different compositions of MYP (mannitol, yeast, and peptone) medium were tested. The most adequate medium was mannitol $25 \mathrm{~g} / \mathrm{L}$, yeast extract $0.625 \mathrm{~g} / \mathrm{L}$, and peptone $0.375 \mathrm{~g} / \mathrm{L}$. Through contour curves, it was determined that strain 086/06 needed supplementation with minerals Mo, B and Mn and vitamins $p$-aminobenzoic acid, pyridoxine and cyanocobalamin. Standard strain CCT 2565 needed supplementation of all minerals and vitamins studied, except inositol. The lower requirement of micronutrients for high cell multiplication of the 086/06 strain may be related to the adaptation of strain $086 / 06$ to industrial production conditions.
\end{abstract}

Keywords: vitamins; minerals; fermentation; bacterial stress response; fermentation technology.

Practical Application: Design of experiments to verify the need for minerals and vitamins for acetic acid bacteria strains.

\section{Introduction}

Vinegar is traditionally produced from alcohol-containing syrup that is obtained from a fermented raw material, which can come from several sources. The group of microorganisms known as acetic bacteria ( $\mathrm{AAB}$ ) performs the transformation of ethanol into acetic acid (Budak et al., 2014). Depending on the raw material, the addition of nutrients, such as vitamins and minerals, might be necessary to a greater or lesser extent (Gullo et al., 2014). From a qualitative point of view, the nutrient requirements of microorganisms are the same of all living beings; to renew their protoplasm and to exert metabolic activities, they need medium supplementation with sources of energy (Hood \& Skaar, 2012).

The microbial cell is formed mainly by carbon, oxygen, hydrogen and nitrogen elements. Phosphorous, sulfur, potassium, magnesium, calcium, sodium, and iron are less abundant, but they are not less important to the vital activities of bacterial metabolism (Spinosa et al., 2015). Micronutrients are fundamental to enzymatic action. In many cases, they work as prosthetic groups or cofactors of important metabolic enzymes (Hood \& Skaar, 2012).

Vitamins are among the most vital growth factors. Most of the time, they act as coenzymes or as important metabolic precursors. They have their biological importance recognized because some organisms cannot synthesize them; thus, they must obtain them from exogenous sources. The vitamins required by most microorganisms are thiamine $\left(B_{1}\right)$, biotin $\left(B_{7}\right)$, pyridoxine
$\left(\mathrm{B}_{6}\right)$ and cyanocobalamin $\left(\mathrm{B}_{12}\right)$ (LeBlanc et al., 2013; Miret \& Munné-Bosch, 2014).

The cell growth and accumulation of metabolic products are influenced strongly by medium compositions. Therefore, screening and evaluation of nutritional requirements for microorganisms is an important step for bioprocess development because the medium's composition can significantly affect the concentration and yield of product and impact on the economy of the process (Gonçalves et al., 2013; Rajendran et al., 2007). As the maintenance of acetic acid bacteria is difficult and there are few studies on this topic, the nutritional requirements of these microorganisms are not well known, especially for vinegar production. Thus, the use of statistical methodologies, such as Design of Experiments (DoE) to verify the need for minerals and vitamins for the growth of acetic acid bacteria isolated from the vinegar industry may help to formulate an ideal medium for this purpose.

The knowledge of microbial nutrition is necessary for the nutrients to be supplied in the suitable form and amount. So, this study aimed to use a fractional factorial design to verify the requirement of minerals and vitamins for two strains of acetic acid bacteria, aiming to increase cell mass production. Because the nutritional requirements may differ from microorganism to microorganism, the strains studied were a high acetic acid producer isolated from the vinegar

Received 01 Feb., 2021

Accepted 22 Apr., 2021

${ }^{1}$ Departamento de Ciência de Alimentos, Faculdade de Engenharia de Alimentos, Universidade Estadual de Campinas - UNICAMP, Campinas, SP, Brasil

${ }^{2}$ Departamento de Ciência e Tecnologia de Alimentos, Centro de Ciências Agrárias, Universidade Estadual de Londrina - UEL, Londrina, PR, Brasil

${ }^{3}$ Departamento de Estatística, Centro de Ciências Exatas, Universidade Estadual de Londrina - UEL, Londrina, PR, Brasil

${ }^{*}$ Corresponding author: wilma.spinosa@uel.br 
production industry and a standard strain of Acetobacter aceti acquired from a culture collection.

\section{Materials and methods}

\subsection{Material}

For the experiments, acetic acid bacteria were isolated and selected previously from a vinegar production industry and maintained in the culture collection of the Food Science and Technology Department (State University of Londrina) under catalog number $086 / 06$. This strain was phenotypically identified as rod-shaped gram-negative bacteria, catalasepositive and capable of oxidizing ethanol and producing acid from glucose. The other strain used was a standard Acetobacter aceti (Pasteur) Beijerinck CCT 2565, donated by Tropical Foundation of Research and Technology "André Tosello" (Campinas - SP, Brazil).

In this study, these strains were identified as 086/06 and CCT 2565 , respectively. The strains were preserved in liquid nitrogen and placed into cryotubes at $-196^{\circ} \mathrm{C}$ with malt extract $(200 \mathrm{~g} / \mathrm{L})$ as cryoprotectant (Spinosa et al., 2015). Five minerals (molybdenum - Mo, boron - B, zinc - Zn, iron - Fe and manganese - Mn) and eight vitamins ( $p$-aminobenzoic acid, thiamin $-B_{1}$, niacin $-\mathrm{B}_{3}$, pantothenic acid $-\mathrm{B}_{5}$, pyridoxine $-\mathrm{B}_{6}$, biotin $-\mathrm{B}_{7}$, cyanocobalamin $-\mathrm{B}_{12}$, and inositol) were also used for analysis. The culture media used was MYP (Mannitol, Yeast extract, Peptone) medium and its versions MYP1, MYP2, MYP3, and MYP4, as shown in Table 1.

The medium contained decreased concentrations of yeast extract and peptone. The basal medium was modified as suggested previously (Asai, 1968). These media and their respective concentrations ensured the minimal supply of minerals and vitamins in the experiments, with the purpose of promoting the growth of microorganisms until a population equal or superior to $20.7 \ln \mathrm{N} / \mathrm{mL}$, without interfering in the cell multiplication during the posterior experiments of micronutrient requirements.

The experiments were performed in a reactor of $8 \mathrm{~L}$ capacity. This fermentor had electronic control of temperature and manual control of oxygen/air intake, which was previously filtered on activated carbon filter before being introduced into the reactor. The fermenter was kept at fixed temperature of $30^{\circ} \mathrm{C}$ and oxygen flow rate of $35 \mathrm{~L} / \mathrm{h}$.

\subsection{Study of the nutritional requirements for inoculum preparation}

To prove that the containing nutrients in the culture medium did not interfere with the mineral and vitamin selection tests, two techniques were used to prepare the inoculum. First, the cells were washed with $25 \mathrm{mM}$ EDTA, centrifuged (Centrifuge 5804R, Eppendorf ${ }^{\oplus}$ AG, Germany) and resuspended in $8.5 \mathrm{~g} / \mathrm{L}$ saline solution (Santos \& Yokoya, 1993). In the second technique, cell cultivation was performed in MYP media and its versions. For this, $0.1 \mathrm{~mL}$ of the reactivated culture was inoculated in MYP and incubated for $24 \mathrm{~h}$ at 30 ${ }^{\circ} \mathrm{C}$ and $120 \mathrm{rpm}$ agitation rate. The suspension was aseptically transferred into tubes containing $5 \mathrm{~mL}$ of each MYP medium (Table 1) in the proportion of one part of the suspension to 10 parts of the medium. The evaluated response was the cell multiplication of microorganisms after 48 hours at $30^{\circ} \mathrm{C}$ and $120 \mathrm{rpm}$ agitation rate. After selecting the culture medium, the assay was repeated for seven cycles, and microorganism cell multiplication was determined for each cycle. An inoculum population equal to or greater than $20.7 \mathrm{ln} \mathrm{N} / \mathrm{mL}$ was used as the criterion for selecting the culture medium.

The inoculum preparation and the increase in volume scale were performed following the forward steps. It started by placing the microorganisms conditioned in cryotubes at $-196{ }^{\circ} \mathrm{C}$ in $50 \mathrm{~mL}$ of MYP growth medium and incubated under the prior described conditions. After turbidity of the medium, $0.1 \mathrm{~mL}$ was transferred to other tubes containing $5 \mathrm{~mL}$ of each version of MYP growth medium, and they were maintained under the same multiplication conditions. Then, the content was aseptically transferred to a bottle containing $50 \mathrm{~mL}$ of the selected growth medium.

To prove that there was no interference of the compounds from the yeast extract and peptone, four control growth media were prepared (Table 2). They were made together with fractional factorial experiments to study nutrient requirements.

Table 1. Composition of growth medium MYP and its versions in $\mathrm{pH} 6.0$.

\begin{tabular}{ccccccc}
\hline Components & Basal & MYP & MYP 1 & MYP 2 & MYP 3 & MYP 4 \\
\hline Yeast extract (g/L) & - & 5.0 & 2.5 & 1.25 & 0.625 & 0.3125 \\
Peptone $(\mathrm{g} / \mathrm{L})$ & - & 3.0 & 1.5 & 0.75 & 0.375 & 0.1875 \\
Mannitol $(\mathrm{g} / \mathrm{L})$ & 25.0 & 25.0 & 25.0 & 25.0 & 25.0 & 25.0 \\
$\left(\mathrm{NH}_{4}\right)_{2} \mathrm{SO}_{4}(\mathrm{~g} / \mathrm{L})$ & 1 & & & & & \\
$\begin{array}{c}\text { Macronutrients } \\
(\mathrm{mL} / \mathrm{L})^{*}\end{array}$ & 5 & & & & & \\
$\begin{array}{c}\text { Ultra-purified water } \\
(\mathrm{mL})\end{array}$ & 1000 & 1000 & 1000 & 1000 & 1000 & 1000 \\
\hline
\end{tabular}

${ }^{*}$ Macronutrients solution: $100.0 \mathrm{~g} / \mathrm{L} \mathrm{KH}_{2} \mathrm{PO}_{4}+100.0 \mathrm{~g} / \mathrm{L} \mathrm{K}_{2} \mathrm{HPO}_{4}+40 \mathrm{~g} / \mathrm{L}$ $\mathrm{MgSO}_{4}$

Table 2. Formulation of control growing medium.

\begin{tabular}{cccccc}
\hline \multirow{2}{*}{$\begin{array}{c}\text { Control } \\
\text { Medium }\end{array}$} & \multicolumn{3}{c}{ Basal medium $^{\star *}$} & \multicolumn{2}{c}{ Selection tests $^{\star * *}$} \\
\cline { 2 - 6 } & C source & N source & $\begin{array}{c}\text { Minerals } \\
(\text { macro })\end{array}$ & Vitamins & Minerals \\
\hline $\mathrm{C}_{1}$ & + & + & + & + & - \\
$\mathrm{C}_{2}$ & + & + & + & - & + \\
$\mathrm{C}_{3}$ & + & + & + & - & - \\
$\mathrm{C}_{4}$ & + & + & - & - & - \\
\hline
\end{tabular}

(+) containing, under the cited concentrations; (-) not containing; ${ }^{*} \mathrm{C}_{\mathrm{n}}=$ growing medium control 1, 2, 3, and $4 ;{ }^{* *} \mathrm{C}$ source $=$ mannitol; ${ }^{* *} \mathrm{~N}$ source $=\left(\mathrm{NH}_{4}\right)_{2} \mathrm{SO}_{4} ;{ }^{* *}$ Minerals (macro): $100.0 \mathrm{~g} / \mathrm{L} \mathrm{KH}_{2} \mathrm{PO}_{4}+100.0 \mathrm{~g} / \mathrm{L} \mathrm{K}_{2} \mathrm{HPO}_{4}+40 \mathrm{~g} / \mathrm{L} \mathrm{MgSO}_{4} ;{ }^{* * *}$ Vitamins and minerals in study. 
Fifty milliliters/L of inoculum was used in the factorial tests. The measurement of multiplication and cellular viability was performed under an optical microscope using a Neubauer chamber and $2 \mathrm{~g} / \mathrm{L}$ Trypan blue vital dye (Spinosa et al., 2015).

\subsection{Experimental design to study the requirement of micronutrients}

To verify the real requirement of micronutrients that affect the cell multiplication of the strains, five minerals and eight vitamins were evaluated according to Asai (1968). Two fractional factorial designs were applied at two levels $\left(2^{\mathrm{k}}\right)$ with a central point to each strain of acetic acid bacteria. To study the influence of minerals, the vitamin concentrations were kept at the maximum as described previously (Asai, 1968). A fractional factorial design $2^{(5-1)}$, consisting of 16 factorial points and 2 central points, was used to evaluate the effects of selected minerals. To study the influence of vitamins, the mineral concentrations were kept at the maximum. A fractional factorial design $2^{(8-3)}$, with 32 factorial points and 2 central points, was used to estimate the effects of selected vitamins. The levels minimum ( -1$)$, maximum $(+1)$, and the central point (0) to each variable are described in Table 3.

The estimated effects, regression coefficients, analysis of variance (ANOVA), and the optimization conditions of essential nutrients to promote bacterial growth were determined using $\mathrm{R}$ software (R Core Team, 2016). For statistical calculations, the variables $\mathrm{M}_{\mathrm{i}}$ or $V_{i}$ were codified as $m_{i}$ or $v_{i}$, where the letter $M$ represents minerals, and $\mathrm{V}$ represents vitamins. The significant effects were selected at the $10 \%$ level because they are biological experiments.

Table 3. Factors and levels used on the factorial design for minerals and vitamins.

\begin{tabular}{|c|c|c|c|c|c|}
\hline & $\mathrm{oblec}(\mathrm{mo} / \mathrm{I})$ & Sumbls & & ified le & \\
\hline & dores (III)/ L) & उу1110018 & -1 & 0 & +1 \\
\hline Minerals & Molybdenum (Mo) & $\mathrm{M}_{1}$ & 0.0 & 0.25 & 0.5 \\
\hline & Boron (B) & $\mathrm{M}_{2}$ & 0.0 & 0.25 & 0.5 \\
\hline & Zinc (Zn) & $\mathrm{M}_{3}$ & 0.0 & 0.25 & 0.5 \\
\hline & Iron $(\mathrm{Fe})$ & $\mathrm{M}_{4}$ & 0.0 & 5.0 & 10.0 \\
\hline & Manganese (Mn) & $\mathrm{M}_{5}$ & 0.0 & 5.0 & 10.0 \\
\hline Vitamins & $\begin{array}{c}P \text {-aminobenzoic } \\
\text { acid }\end{array}$ & $\mathrm{V}_{1}$ & 0.0 & 0.1 & 0.2 \\
\hline & Thiamine $\left(\mathrm{B}_{1}\right)$ & $\mathrm{V}_{2}$ & 0.0 & 0.5 & 1.0 \\
\hline & $\begin{array}{l}\text { Nicotinic acid } \\
\left(\text { niacin- } B_{3}\right)\end{array}$ & $\mathrm{V}_{3}$ & 0.0 & 0.1 & 0.2 \\
\hline & $\begin{array}{l}\text { Pantothenic acid } \\
\qquad\left(\mathrm{B}_{5}\right)\end{array}$ & $\mathrm{V}_{4}$ & 0.0 & 0.25 & 0.5 \\
\hline & Inositol & $\mathrm{V}_{5}$ & 0.0 & 2.5 & 5.0 \\
\hline & Pyridoxine $\left(\mathrm{B}_{6}\right)$ & $\mathrm{V}_{6}$ & 0.0 & 400.0 & 800.0 \\
\hline & Biotin $\left(B_{7}\right)$ & $\mathrm{V}_{7}$ & 0.0 & 0.4 & 0.8 \\
\hline & $\begin{array}{c}\text { Cyanocobalamin } \\
\left(\mathrm{B}_{12}\right)\end{array}$ & $\mathrm{V}_{8}$ & 0.0 & 0.5 & 1.0 \\
\hline
\end{tabular}

The cell multiplication $(Y)$ to $086 / 06$ and CCT 2565 strains were obtained by measuring the optical density using a UV-Vis spectrophotometer (Genesis 6, Thermo Electron Corporation, USA) at a wavelength of $600 \mathrm{~nm}$ (Lanciotti et al., 2001). The optical density was determined between 0 and 96 hours after incubation.

\section{Results and discussion}

\subsection{Inoculum preparation}

Different techniques were used to prepare the inoculum because acetic acid bacteria have multiplication deficiency depending on how they are handled (Gomes et al., 2018).

The technique in which the inoculum was prepared in MYP medium without centrifugation, washing, and cell resuspension was rejected because it interfered with the various components in the medium. The same medium was used with modifications in the preparation procedures. The cells were centrifuged, washed in $25 \mathrm{mM}$ EDTA solution and resuspended in $8.5 \mathrm{~g} / \mathrm{L}$ saline solution. This technique was also inadequate to eliminate the interference of nutrients in the culture medium. Lastly, minimum concentrations of nutrients were tested in different versions of MYP medium, so it would not affect cell multiplication. The obtained results of viable cells $(\ln \mathrm{N} / \mathrm{mL})$ for the $086 / 06$ and CCT 2565 strains are shown in Table S1, Supplementary Material.

MYP versions 1 and 2 were not selected because they were intended to use lower concentrations of yeast extract and peptone to avoid interference from medium components in the acetic acid bacteria micronutrient requirement tests. MYP version 4 was excluded because the counting of viable cells was lower than $20.7 \ln \mathrm{N} / \mathrm{mL}$. Additionally, a decrease in cell sizes was observed under optical microscopy, and its typical arrangement in strings was not noticed.

Based on viable cell values, MYP medium version 3 was selected for both strains. An inoculum is considered viable when it presents a population equal to or higher than $20.7 \ln$ $\mathrm{N} / \mathrm{mL}$ (Sokollek \& Hammes, 1997; Spinosa et al., 2015). The experiments named Control Medium $\left(\mathrm{C}_{1}, \mathrm{C}_{2}, \mathrm{C}_{3}\right.$, and $\left.\mathrm{C}_{4}\right)$ were useful in the fractional factorial design to confirm that the minimum concentration of complex components in the medium did not interfere with nutrient selection tests (Supplementary Material, Tables S2 and S3).

The cell population for both strains of acetic acid bacteria, in seven consecutive cycles in MYP medium version 3, after 96 hours, remained constant with optical density values of $0.286 \pm 0.018(086 / 06)$ and $0.289 \pm 0.014$ (CCT 2565).

\subsection{Selection of minerals and vitamins}

The matrix and the obtained results of the fractional factorial design for cell multiplication of 086/06 and CCT 2565 strains with different concentrations of minerals and vitamins are shown in Tables S2 and S3.

Equations 1 and 2 show the significant effects of minerals on the regressions of independent variables depending on the response $(Y)$ for strains 086/06 and CCT 2565. 
Y086 $/ 06=0.21489+0.02069 m 1-0.08531 m 2-0.04581 m 5-$ $0.15956 m 1 m 2-0.10931 m 1 m 5+0.17569 m 2 m 5$

YCCT $2565=0.241556+0.001500 m 1-$

$0.000500 m 2-0.018500 m 3+0.059500 m 4-0.004500 m x 5+$

$0.038500 m 2 m 4-0.024500 m 3 m 5+0.023500 m 1 m 3$

Evaluating the estimated effects for the 086/06 strain, it is considered that the minerals molybdenum $\left(m_{1}\right)$, boron $\left(m_{2}\right)$, and manganese $\left(m_{5}\right)$ were significant within the experimental domain studied. For the CCT 2565 strain, all minerals had significant effects.

The ANOVA results for minerals (Table 4) show no lack of adjustment for the models, with $\mathrm{R}^{2}$ values for $086 / 06$ and CCT 2565 strains of 0.7862 and 0.8259 , respectively. $R^{2}$ values less than 0.8 are considered to be less predictive from the statistical point of view; however, other authors reported that in preliminary studies, values near 0.6 could also be considered (Capanzana \& Buckle, 1997).

The minerals iron and zinc were only required for the CCT 2565 strain. Iron is an element that participates in the cytochrome complex of bacteria and is a component of catalases, peroxidases, oxidases and all nitrogenases (Madigan et al., 2016). The bacteria belonging to the Acetobacter genus are positive catalases and negative oxidases. The cytochromes $\mathrm{a}_{1}, \mathrm{a}_{2}, \mathrm{a}_{4}, \mathrm{~b}, \mathrm{c}, \mathrm{c}_{1}$, and $\mathrm{d}$ have been found in Acetobacter, but they are not always present

Table 4. ANOVA for the selection of minerals for 086/06 and standard CCT 2565 strains.

\begin{tabular}{|c|c|c|c|c|c|}
\hline & \multicolumn{5}{|c|}{$086 / 06$} \\
\hline & $d f$ & SS & MS & F-value & p-value \\
\hline Linear $\left(m_{1}, m_{2}, m_{5}\right)$ & 3 & 0.15688 & 0.05229 & 1.6928 & 0.225845 \\
\hline Interaction $\mathrm{m}_{1} \mathrm{~m}_{2}$ & 1 & 0.40736 & 0.40736 & 13.1868 & 0.003947 \\
\hline Interaction $\mathrm{m}_{1} \mathrm{~m}_{5}$ & 1 & 0.19119 & 0.19119 & 6.1890 & 0.030155 \\
\hline Interaction $\mathrm{m}_{2} \mathrm{~m}_{5}$ & 1 & 0.49386 & 0.49386 & 15.9868 & 0.002092 \\
\hline Residues & 11 & 0.33981 & 0.03089 & & \\
\hline Lack of adjustment & 2 & 0.11175 & 0.05587 & 2.2049 & 0.166218 \\
\hline Pure error & 9 & 0.22806 & 0.02534 & - & - \\
\hline $\mathrm{R}^{2}$ & & & 0.7862 & & \\
\hline \multirow[t]{3}{*}{ Adjusted $\mathrm{R}^{2}$} & & & 0.6695 & & \\
\hline & \multicolumn{5}{|c|}{ CCT 2565} \\
\hline & $d f$ & SS & MS & F-value & p-value \\
\hline $\begin{array}{c}\text { Linear } \\
\left(\mathrm{m}_{1}, \mathrm{~m}_{2}, \mathrm{~m}_{3}, \mathrm{~m}_{4,} \mathrm{~m}_{5}\right)\end{array}$ & 5 & 0.062484 & 0.0124968 & 5.1002 & 0.01709 \\
\hline Interaction $\mathrm{m}_{2} \mathrm{~m}_{4}$ & 1 & 0.023716 & 0.023716 & 9.6789 & 0.01250 \\
\hline Interaction $\mathrm{m}_{3} \mathrm{~m}_{5}$ & 1 & 0.009604 & 0.009604 & 3.9196 & 0.07909 \\
\hline Interaction $\mathrm{m}_{1} \mathrm{~m}_{3}$ & 1 & 0.008836 & 0.008836 & 3.6061 & 0.09003 \\
\hline Residues & 9 & 0.022052 & 0.0024503 & & \\
\hline Lack of adjustment & 8 & 0.020252 & 0.0025316 & 1.4064 & 0.57640 \\
\hline Pure error & 1 & 0.0018 & 0.0018 & & \\
\hline $\mathrm{R}^{2}$ & & & 0.8259 & & \\
\hline Adjusted $\mathrm{R}^{2}$ & & & 0.6712 & & \\
\hline
\end{tabular}

together. Cytochrome $\mathrm{a}_{1}$ seems to be typical of Acetobacter and is not detected in Gluconobacter (Bachi \& Ettlinger, 1974). Zinc is an element present in membrane-bound pyrroloquinoline quinone (PQQ)-dependent alcohol dehydrogenase (ADH). This enzyme is fundamental in the bioconversion of ethanol to acetic acid through two sequential reactions. Zinc is also present in RNA and DNA polymerases (Gomes et al., 2018; Mondal \& Bose, 2019).

The minerals boron, manganese and molybdenum, were required for both 086/06 and CCT 2565 strains. Boron is a micronutrient with biological functions that are still poorly understood. For bacteria, boron serves as a chemical sensor for communication between microorganisms. This characteristic allows cellular density control (Madigan et al., 2016; Řezanka \& Sigler, 2008). Manganese is a phosphate group transfer enzyme cofactor responsible for the nonspecific activation of hydrolases, kinases, decarboxylases, and transferases.

In some cases, it substitutes the $\mathrm{Mg}^{2+}$ ion in the nucleic acid polymerase system. Manganese is also an essential and very important trace element in the cellular physiology of prokaryotes and eukaryotes (Florkin \& Stotz, 2014; Madigan et al., 2016; Mondal \& Bose, 2019). Molybdenum has a cellular function in several enzymes that contain flavin and in nitrogenases, reductases, and some dehydrogenases. Together with iron and flavin, it participates in the enzymatic action during the process of electron transfer from substrate to oxygen (Hänsch \& Mendel, 2009; Madigan et al., 2016). Other authors have also described the necessity of molybdenum for nitrogen fixation in Acetobacter strains (Anke et al., 2007).

Equations 3 and 4 show the significant effect of vitamins for the regression of independent variables depending on the response $(Y)$ for 086/06 and CCT 2565 strains.

$\mathbf{Y 0 8 6} / \mathbf{8 6}=0.1635000-0.0059375 v 1-0.0391250 v 6+$

$0.0060000 v 8-0.0999375 v 12-0.0080625 v 6 v 8$

YCCT $2565=0.1146765+0.0078750 v 1+0.0060625 v 2+$

$0.0063125 v 3+0.0045625 v 40.0051250 v 6-0.0006250 v 7+$

$0.0014375 v 8-0.0048125 v 1 v 2-0.0043125 v 1 v 3-$

$0.0053750 v 1 v 6+0.0038125 v 7 v 8$

Evaluating the estimated effects for the $086 / 06$ strain, it is considered that vitamins $p$-aminobenzoic acid $\left(v_{1}\right)$, pyridoxine $\left(v_{6}\right)$, and cyanocobalamin $\left(v_{8}\right)$ were significant within the experimental domain studied. For the CCT 2565 strain, all vitamins had a significant effect, except inositol (v5).

The models evaluated by ANOVA (Table 5) for vitamins showed coefficients of determination $\left(\mathrm{R}^{2}\right)$ of 0.8525 for the $086 / 06$ strain and of 0.7356 for the CCT 2565 strain. Regression deviations of vitamin models were not significant at the $5 \%$ level for $086 / 06(p=0.4256)$ and CCT $2565(p=0.2249)$ strains.

According to other authors, in a synthetic medium with mannitol as a carbon source, acetic acid bacteria need supplementation with $p$-aminobenzoic acid, niacin, thiamin, 
Table 5. ANOVA for the selection of vitamins for 086/06 and standard CCT 2565 strains.

\begin{tabular}{|c|c|c|c|c|c|}
\hline & \multicolumn{5}{|c|}{ 086/06 } \\
\hline & $d f$ & SS & MS & F-value & p-value \\
\hline Linear $\left(\mathrm{v}_{1}, \mathrm{v}_{6}, \mathrm{v}_{8}\right)$ & 3 & 0.051265 & 0.0170882 & 38.3401 & $4.761 \mathrm{e}^{-10}$ \\
\hline Quadratic $v_{1}^{2}$ & 1 & 0.018800 & 0.018800 & 42.1808 & $4.887 \mathrm{e}^{-07}$ \\
\hline Interaction $\mathrm{v}_{6} \mathrm{v}_{8}$ & 1 & 0.002080 & 0.0020801 & 4.6671 & 0.03945 \\
\hline Residues & 28 & 0.012480 & 0.0004457 & & \\
\hline Lack of adjustment & 3 & 0.001293 & 0.0004309 & 0.9629 & 0.42566 \\
\hline Pure error & 25 & 0.011187 & 0.0004475 & & \\
\hline $\mathrm{R}^{2}$ & & & 0.8525 & & \\
\hline \multirow[t]{3}{*}{ Adjusted $\mathrm{R}^{2}$} & & & 0.8262 & & \\
\hline & \multicolumn{5}{|c|}{ CCT 2565} \\
\hline & $d f$ & SS & MS & F-value & p-value \\
\hline $\begin{array}{c}\text { Linear } \\
\left(\mathrm{v}_{1}, \mathrm{v}_{2}, \mathrm{v}_{3}, \mathrm{v}_{4}, \mathrm{v}_{6}, \mathrm{v}_{7}, \mathrm{v}_{8}\right)\end{array}$ & 7 & 0.0060210 & 0.00086014 & 6.0177 & 0.0005265 \\
\hline Interaction $\mathrm{v}_{1} \mathrm{v}_{2}$ & 1 & 0.0007411 & 0.00074113 & 5.1851 & 0.0328606 \\
\hline Interaction $\mathrm{v}_{1} \mathrm{v}_{3}$ & 1 & 0.0005951 & 0.00059513 & 4.1636 & 0.0534822 \\
\hline Interaction $\mathrm{v}_{1} \mathrm{v}_{6}$ & 1 & 0.0009245 & 0.00092450 & 6.4680 & 0.0185270 \\
\hline Interaction $\mathrm{v}_{7} \mathrm{v}_{8}$ & 1 & 0.0004651 & 0.00046513 & 3.2541 & 0.0849563 \\
\hline Residues & 22 & 0.0031446 & 0.00014293 & & \\
\hline Lack of adjustment & 21 & 0.0031321 & 0.00014915 & 11.9317 & 0.2249626 \\
\hline Pure error & 1 & 0.0000125 & 0.00001250 & & \\
\hline $\mathrm{R}^{2}$ & & & 0.7356 & & \\
\hline Adjusted $\mathrm{R}^{2}$ & & & 0.6033 & & \\
\hline
\end{tabular}

$d f=$ degrees of freedom; $S S=$ sum of squares; MS = mean square.

and pantothenic acid (Sievers \& Swings, 2015). In this study, for the CCT 2565 strain, the need for supplementation with these vitamins, except inositol, was confirmed. Both strains 086/06 and CCT 2565 required the vitamins $p$-aminobenzoic acid, pyridoxine, and cyanocobalamin. The $p$-aminobenzoic acid is a precursor of folic acid and plays an important role in the carbon metabolism and transference of the methyl, formyl, hydroxymethyl group as, for example, during the synthesis of purines and pyrimidines, which are essential for the synthesis of DNA. p-Aminobenzoic acid is a growth factor with proven biological effects, mainly in bacteria and fungi (Crisan et al., 2014). Pyridoxine is an important vitamin involved in the metabolism of amino acids, keto acids, carbohydrates, neurotransmitters and lipids ( $\mathrm{Wu} \& \mathrm{Lu}, 2012$ ). Cyanocobalamin contributes to the metabolism of carbohydrates, proteins and fats and participates in the synthesis of deoxyribose (Madigan et al., 2016; Prikhnenko, 2015).

The other vitamins, namely, thiamine, niacin, pantothenic acid and biotin, were required only for the CCT 2565 strain. Thiamine is a coenzyme of pyruvate dehydrogenase (PDH), which catalyzes the decarboxylation of pyruvate to produce acetyl $\mathrm{CoA}$ and plays an important role in carbohydrate metabolism (Choi et al., 2013; Gibson et al., 2016). Niacin is a precursor of nicotinamide adenine dinucleotide (NAD) and nicotinamide adenine dinucleotide phosphate (NADP) that are involved in many biochemical reactions, including energy production from carbohydrates, fats and proteins and biosynthesis of various molecules (Lanska, 2012; Prikhnenko, 2015).

Pantothenic acid and biotin are growth factors for many microorganisms. Pantothenic acid is a precursor of coenzyme $A$, which is involved in a series of oxidative reactions and is also essential in the generation of energy from carbohydrates, fats and proteins and the synthesis of various biomolecules. Biotin is a vitamin involved as a cofactor in the synthesis of fatty acids and amino acid catabolism (Yao et al., 2018). Other authors demonstrated that biotin promoted the growth of Acetobacter suboxydans. Pantothenic acid was also established as an essential growth factor for this strain (Underkofler et al., 1942).

As observed, for strain $086 / 06$, isolated from an industrial process of vinegar fabrication, the requirement of vitamins was different. It only needed $p$-aminobenzoic acid, pyridoxine, and cyanocobalamin. The CCT 2565 strain, which was maintained in a culture collection, may need more supplementation to produce acetic acid. In previous kinetic studies, it was verified that the $086 / 06$ strain has a conversion capacity of ethanol to acetic acid above $80 \%$, superior to CCT 2565 (data not shown). Possibly because the $086 / 06$ strain comes from industry and is 

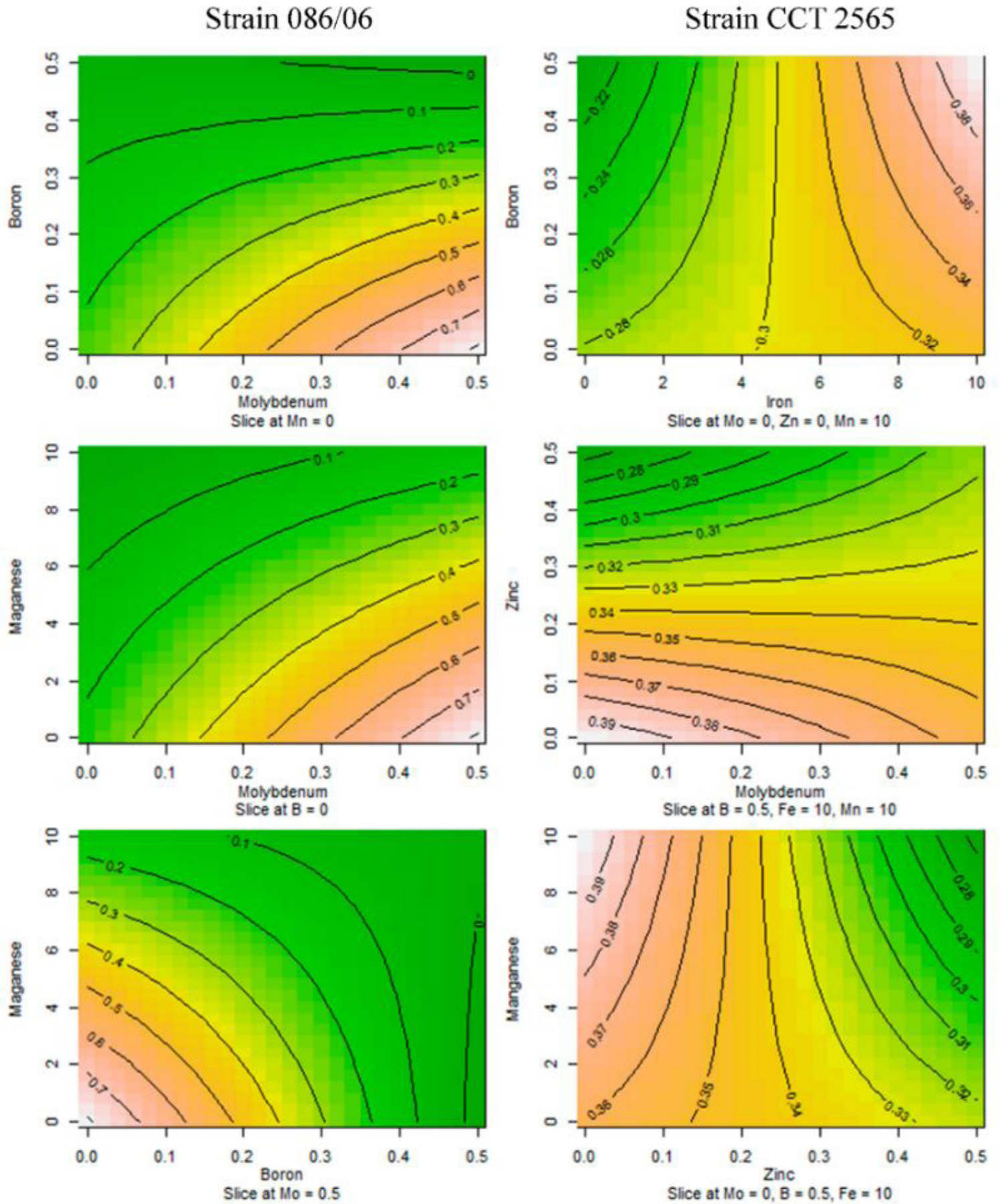

Figure 1. Contour curves for optical density (O.D.) (Y) in the selection of minerals for 086/06 and CCT 2565 strains. B: boron; Fe: iron; Mn: manganese; Mo: molybdenum; Zn: zinc.

well adapted to favorable acid production conditions, this ability has been maintained even in other growing conditions and may explain why some minerals and vitamins are not needed for its cellular growth.

Contour curves were generated using Equations 1 and 2 for minerals (Figure 1), and Equations 3 and 4 for vitamins (Figure 2). They were obtained to verify the influence of the quantity of each selected micronutrient on greater cell production. Figure 1 shows, in an illustrative way, the contour curves of some possible mineral interactions, setting the other variables at their optimal value.

The interactions between the molybdenum, boron and manganese minerals, which were selected for supplementation of the Acetobacter 086/06 strain, indicate a tendency to use very 

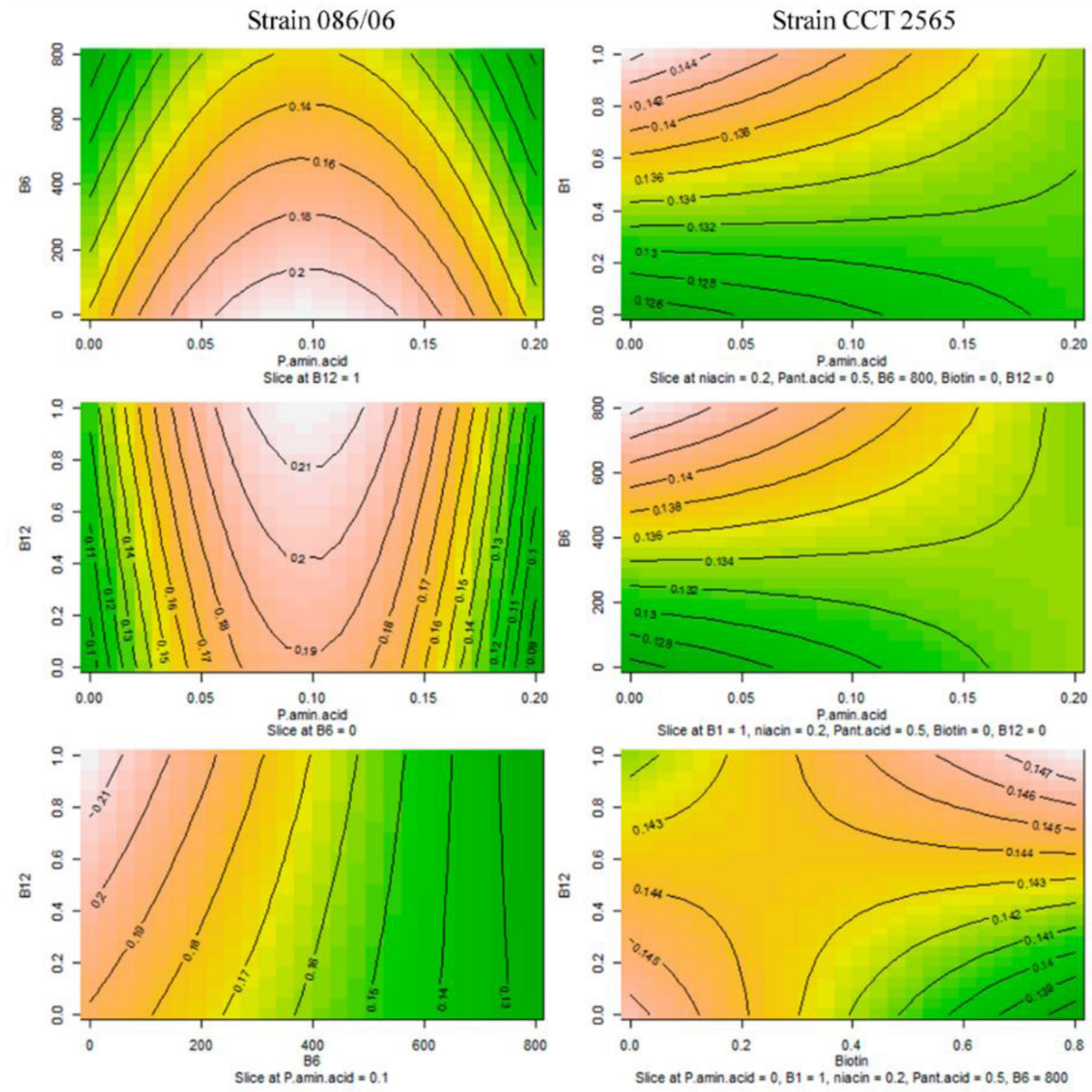

Figure 2. Contour curves for optical density (O.D.) (Y) in the selection of vitamins for 086/06 and CCT 2565 strains. B1: thiamine; B3: niacin; B6: pyridoxine; B7: biotin; B12: cyanocobalamin; P. amin. acid: P-aminobenzoic acid.

low concentrations of manganese and boron. For industry, this may indicate higher productivity with lower use of these minerals. However, the contour curves indicate that supplementation with molybdenum should be performed at elevated concentrations, approximately $0.5 \mathrm{mg} / \mathrm{L}$, to achieve greater cell multiplication.

For the CCT 2565 strain, Figure 1 did not present all possible interactions between the required minerals of this Acetobacter, but it can be noticed, for example, that boron can be used in a concentration range of 0.0 to $0.5 \mathrm{mg} / \mathrm{L}$ if the iron concentration is maintained close to $10.0 \mathrm{mg} / \mathrm{L}$. Zinc can be used in a concentration range of 0.0 to $0.5 \mathrm{mg} / \mathrm{L}$ if the concentration of molybdenum is quite low and that of manganese is close to $10.0 \mathrm{mg} / \mathrm{L}$.

The Figure 2 shows contour curves of some possible interactions of vitamins, setting the other variables at their optimal value.
For the $086 / 06$ strain, vitamin pyridoxine may be supplemented at concentrations ranging from 0.0 to $400.0 \mathrm{mg} / \mathrm{L}$ with cyanocobalamin supplementation ranging from 0.5 to 1.0 $\mathrm{mg} / \mathrm{L}$ if the concentration of $p$-aminobenzoic acid is maintained at approximately $0.1 \mathrm{mg} / \mathrm{L}$. The interaction of pyridoxine with cyanocobalamin reinforces that for increased cell production of the 086/06 acetic acid bacteria, pyridoxine supplementation should be minimal, while the cyanocobalamin concentration should be close to the maximum used in the experimental design $(1.0 \mathrm{mg} / \mathrm{L})$.

For the standard CCT 2565 strain, the interactions shown in the Figure 2 indicate that very low concentrations of $p$-aminobenzoic acid are required, whereas thiamine, pyridoxine, and niacin should be supplemented at the maximum concentration used in 
the experimental design $(1.0,800.0$, and $0.2 \mathrm{mg} / \mathrm{L}$, respectively) to obtain greater cell multiplication.

The interaction of biotin and cyanocobalamin showed that these vitamins are directly dependent and can be used at any concentration within the limit used in the experimental design, as long as both are low or high concentrations. However, the interaction of cyanocobalamin with other vitamins showed that supplementation with this vitamin should be low to obtain high cellular multiplication of the standard CCT 2565 strain. In this way, biotin supplementation should also be minimal. This can mean higher productivity with less use of these vitamins.

These results show that it is possible to obtain an optimization of the mineral and vitamin concentrations that should be supplemented to obtain high cell production of both $086 / 06$ and CCT 2565 strains. It is emphasized that the 086/06 strain from the industrial process presents characteristics inherent in the high conversion rates of ethanol to acetic acid even though it requires fewer nutrients when compared to the standard strain. This can be the result of the adaptation of this strain to the conditions of industrial production.

\section{Conclusion}

This study showed that not all strains of acetic acid bacteria have the same requirement of micronutrients. The fractional factorial experimental design allowed the selection of minerals and vitamins for each strain studied. The 086/06 strain, isolated from the vinegar industry, required a lower number of different micronutrients than the CCT 2565 strain. It is possible that the adaptation of the $086 / 06$ strain to the conditions of industrial production promoted high cellular multiplication with less supplementation. This study also made it possible to verify a proximal concentration that should be used for each micronutrient required. However, future research using response surface methodology may be helpful to obtain the exact concentration of each micronutrient needed by acetic acid bacteria.

\section{Acknowledgements}

The authors thank the Professor Ph.D. Fumio Yokoya, University of Campinas, State University of Londrina, Tecnologia em Saúde, Indústria, Comércio e Serviços $L t d a$, and Conselho Nacional de Desenvolvimento Científico e Tecnológico (CNPq) for providing research fellowship (Grant number: 307846/2020-2).

\section{References}

Anke, M., Seifert, M., Holzinger, S., Müller, R., \& Schäfer, U. (2007). The biological and toxicological importance of molybdenum in the environment and in the nutrition of plants, animals and man - Part 2: Molybdenum in animals and man. Acta Biologica Hungarica, 58(3), 325-333. http://dx.doi.org/10.1556/ABiol.58.2007.3.8. PMid:17899789.

Asai, T. (1968). Acetic acid bacteria: classification and biochemical activities. Tokyo: University of Tokyo Press.

Bachi, B., \& Ettlinger, L. (1974). Cytochrome difference spectra of acetic acid bacteria. International Journal of Systematic Bacteriology, 24(2), 215-220. http://dx.doi.org/10.1099/00207713-24-2-215.
Budak, N. H., Aykin, E., Seydim, A. C., Greene, A. K., \& Guzel-Seydim, Z. B. (2014). Functional properties of vinegar. Journal of Food Science, 79(5), R757R7. http://dx.doi.org/10.1111/1750-3841.12434. PMid:24811350.

Capanzana, M. V., \& Buckle, K. A. (1997). Optimisation of germination conditions by response surface methodology of a high amylose rice (Oryza sativa) cultivar. Lebensmittel-Wissenschaft + Technologie, 30(2), 155-163. http://dx.doi.org/10.1006/fstl.1996.0142.

Choi, S.-K., Baek, S.-H., \& Choi, S.-W. (2013). The effects of endurance training and thiamine supplementation on anti-fatigue during exercise. Journal of Exercise Nutrition \& Biochemistry, 17(4), 189198. http://dx.doi.org/10.5717/jenb.2013.17.4.189. PMid:25566430.

Crisan, M. E., Bourosh, P., Maffei, M. E., Forni, A., Pieraccini, S., Sironi, M., \& Chumakov, Y. M. (2014). Synthesis, crystal structure and biological activity of 2-hydroxyethylammonium salt of p-Aminobenzoic acid. PLoS One, 9(7), e101892. http://dx.doi.org/10.1371/journal. pone.0101892. PMid:25054237.

Florkin, M., \& Stotz, E. H. (2014). Metabolism of vitamins and trace elements: comprehensive biochemistry (21st ed.). Amsterdan: Elsevier.

Gibson, G. E., Hirsch, J. A., Fonzetti, P., Jordan, B. D., Cirio, R. T., \& Elder, J. (2016). Vitamin B1 (thiamine) and dementia. Annals of the New York Academy of Sciences, 1367(1), 21-30. http://dx.doi. org/10.1111/nyas.13031. PMid:26971083.

Gomes, R. J., Borges, M. D. F., Rosa, M. D. F., Castro-Gómez, R. J. H., \& Spinosa, W. A. (2018). Acetic acid bacteria in the food industry: systematics, characteristics and applications. Food Technology and Biotechnology, 56(2), 139-151. http://dx.doi.org/10.17113/ ftb.56.02.18.5593. PMid:30228790.

Gonçalves, F. A. G., Colen, G., \& Takahashi, J. A. (2013). Optimization of cultivation conditions for extracellular lipase production by Yarrowia lipolytica using response surface method. African Journal of Biotechnology, 12(17), 2270-2278. http://dx.doi.org/10.5897/ AJB2012.3019.

Gullo, M., Verzelloni, E., \& Canonico, M. (2014). Aerobic submerged fermentation by acetic acid bacteria for vinegar production: Process and biotechnological aspects. Process Biochemistry, 49(10), 15711579. http://dx.doi.org/10.1016/j.procbio.2014.07.003.

Hänsch, R., \& Mendel, R. R. (2009). Physiological functions of mineral micronutrients $(\mathrm{Cu}, \mathrm{Zn}, \mathrm{Mn}, \mathrm{Fe}, \mathrm{Ni}, \mathrm{Mo}, \mathrm{B}, \mathrm{Cl})$. Current Opinion in Plant Biology, 12(3), 259-266. http://dx.doi.org/10.1016/j. pbi.2009.05.006. PMid:19524482.

Hood, M. I., \& Skaar, E. P. (2012). Nutritional immunity: Transition metals at the pathogen-host interface. Nature Reviews. Microbiology, 10(8), 525-537. http://dx.doi.org/10.1038/nrmicro2836. PMid:22796883.

Lanciotti, R., Sinigaglia, M., Gardini, F., Vannini, L., \& Guerzoni, M. E. (2001). Growth/no growth interfaces of Bacillus cereus, Staphylococcus aureus and Salmonella enteritidis in model systems based on water activity, $\mathrm{pH}$, temperature and ethanol concentration. Food Microbiology, 18(6), 659-668. http://dx.doi.org/10.1006/ fmic.2001.0429.

Lanska, D. J. (2012). The discovery of niacin, biotin, and pantothenic acid. Annals of Nutrition \& Metabolism, 61(3), 246-253. http://dx.doi. org/10.1159/000343115. PMid:23183297.

LeBlanc, J. G., Milani, C., de Giori, G. S., Sesma, F., van Sinderen, D., \& Ventura, M. (2013). Bacteria as vitamin suppliers to their host: A gut microbiota perspective. Current Opinion in Biotechnology, 24(2), 160-168. http://dx.doi.org/10.1016/j.copbio.2012.08.005. PMid:22940212. 
Madigan, M. T., Martinko, J. M., Bender, K. S., Buckley, D. H., Stahl, D. A., \& Fonseca, F. G. (2016). Microbiologia de Brock (14th ed.). Porto Alegre: Artmed.

Miret, J. A., \& Munné-Bosch, S. (2014). Plant amino acid-derived vitamins: biosynthesis and function. Amino Acids, 46(4), 809-824. http://dx.doi.org/10.1007/s00726-013-1653-3. PMid:24368523.

Mondal, S., \& Bose, B. (2019). Impact of micronutrient seed priming on germination, growth, development, nutritional status and yield aspects of plants. Journal of Plant Nutrition, 42(19), 2577-2599. http://dx.doi.org/10.1080/01904167.2019.1655032.

Prikhnenko, S. (2015). Polycomponent mesotherapy formulations for the treatment of skin aging and improvement of skin quality. Clinical, Cosmetic and Investigational Dermatology, 8, 151-157. http://dx.doi. org/10.2147/CCID.S76721. PMid:25897252.

R Core Team. (2016). R: a language and environment for statistical computing. Vienna: R Foundation for Statistical Computing.

Rajendran, A., Sundaramurthy, A. B., \& Thangavelu, V. (2007). Statistical evaluation of medium components using Plackett-Burman experimental design and kinetic modeling of lipase production by Bacillus sphaericus. Chemical and Biochemical Engineering Quarterly, 21(2), 181-188.

Řezanka, T., \& Sigler, K. (2008). Biologically active compounds of semi-metals. Studies in Natural Products Chemistry, 35(3), 835-921. http://dx.doi.org/10.1016/S1572-5995(08)80018-X. PMid:17991498.

Santos, M. T., \& Yokoya, F. (1993). Characteristics of yeast cell flocculation by Lactobacillus fermentum. Journal of Fermentation and Bioengineering, 75(2), 151-154. http://dx.doi.org/10.1016/0922338X(93)90228-Z.

Sievers, M., \& Swings, J. (2015). Acetobacter. In Bergey's Manual Trust (Ed.), Bergey's manual of systematics of Archaea and Bacteria (pp. 1-7). New York: Springer. https://doi.org/10.1002/9781118960608. gbm00876.

Sokollek, S. J., \& Hammes, W. P. (1997). Description of a starter culture preparation for vinegar fermentation. Systematic and Applied Microbiology, 20(3), 481-491. http://dx.doi.org/10.1016/S07232020(97)80017-3.

Spinosa, W. A., Santos, V. Jr., Galvan, D., Fiorio, J. L., \& Gomez, R. J. H. C. (2015). Vinegar rice (Oryza sativa L.) produced by a submerged fermentation process from alcoholic fermented rice. Food Science and Technology, 35(1), 196-201. http://dx.doi.org/10.1590/1678457X.6605.

Underkofler, L. A., Bantz, A. C., Peterson, W. H., \& State, I. (1942). Growth factors for bacteria. Nutrition Reviews, 8(5), 132-133. http:// dx.doi.org/10.1111/j.1753-4887.1950.tb02399.x. PMid:15423800.

Wu, X., \& Lu, L. (2012). Vitamin B6 deficiency, genome instability and cancer. Asian Pacific Journal of Cancer Prevention, 13(11), 5333-5338. http://dx.doi.org/10.7314/APJCP.2012.13.11.5333. PMid:23317180.

Yao, C., Chou, J., Wang, T., Zhao, H., \& Zhang, B. (2018). Pantothenic acid, vitamin $\mathrm{C}$, and biotin play important roles in the growth of Lactobacillus helveticus. Frontiers in Microbiology, 9(1194), 1194. http://dx.doi.org/10.3389/fmicb.2018.01194. PMid:29922266. 


\section{Supplementary Material}

Supplementary material accompanies this paper.

Table S1 - Viable cell count (ln N/mL) for the different growth medium.

Table S2 - Coded and decoded values of the factorial planning 2(5-1) to study the effect of minerals in cultivation of acetic bacteria. Table S3 - Coded and decoded values of the factorial planning 2(8-3) to study the effect of vitamins in cultivation of acetic bacteria. This material is available as part of the online article from http://www.scielo.br/CTA 